\title{
PENINGKATAN MUTU PENELITIAN DI INDONESIA DALAM MENGATASI MASALAH PENDIDIKAN
}

\author{
Saleh Hidayat ${ }^{1)}$ a) \\ ${ }^{1)}$ Program Pascasarjana, Universitas Muhammadiyah Palembang \\ Jalan Jenderal Ahmad Yani 13 Ulu Palembang \\ a) salehhidayat29@gmail.com
}

\begin{abstract}
PISA 2003, 2006,2009, 2012, and 2015 results show that Indonesian students' ability for reading, science, and mathematic aspect are still in ten lowest ability countries. However, data reality in field show the research amount especially in education scope are very large. The existence of a gap between research potential that can be produced by survey results of PISA 2013-2017 bring up the statements 1) what causes the implementation of Indonesia research does not have significant impact on increasing Indonesia's ranking in PISA? and 2) how the efforts that can be done in improving Indonesia research quality? The study result indicates that there are three main factors causing research quality in Indonesia are still low 1) the obstacles at government policy level; 2) subtract the researchers with doctoral qualification, and 3) the low growth potential of research atmosphere in Indonesia. Efforts that can be done 1) create conducive policy for researchers; 2) add the acceptance quota for doctor's scholarship under 40 years old; 3) add of quota's budget for research, and 4) downstream the research results to the teachers in improving the learning process. Conclusions on Indonesia research quality have been a lot, but need a good management by downstream the research mapping to the obvious community.
\end{abstract}

Keywords: Research, Education, Problem.

\section{ABSTRAK}

Hasil PISA 2003, 2006, 2009, 2012, dan 2015 menunjukkan bahwa kemampuan siswa Indonesia untuk membaca, sains, dan aspek matematika masih berada di sepuluh negara dengan kemampuan terendah. Namun, kenyataan data di lapangan menunjukkan jumlah penelitian terutama dalam lingkup pendidikan sangat besar. Adanya kesenjangan antara potensi penelitian yang dapat dihasilkan oleh hasil survei PISA 2013 -2017 memunculkan pernyataan 1) apa yang menyebabkan pelaksanaan penelitian di Indonesia tidak memiliki dampak yang signifikan terhadap peningkatan peringkat Indonesia dalam PISA? dan 2) bagaimana upaya yang dapat dilakukan dalam meningkatkan kualitas riset Indonesia? Hasil studi menunjukkan bahwa ada tiga faktor utama yang menyebabkan kualitas penelitian di Indonesia masih rendah 1) hambatan di tingkat kebijakan pemerintah; 2) kurangi peneliti dengan kualifikasi doktoral, dan 3) potensi pertumbuhan rendah atmosfer penelitian di Indonesia. Upaya yang dapat dilakukan 1) menciptakan kebijakan yang kondusif bagi peneliti; 2) tambahkan kuota penerimaan untuk beasiswa dokter di bawah 40 tahun; 3) menambah anggaran kuota untuk penelitian, dan 4) menurunkan hasil penelitian kepada guru dalam meningkatkan proses pembelajaran. Kesimpulan tentang kualitas penelitian Indonesia sudah banyak, tetapi membutuhkan manajemen yang baik dengan mengolah pemetaan hilir ke masyarakat yang jelas.

Kata Kunci : Penelitian, Pendidikan, Masalah

\section{PENDAHULUAN}

Kajian permasalahan pendidikan selalu menjadi topik yang cukup menarik untuk dibicarakan. Topik ini selalu ada baik di tingkat pendidikan Sekolah Dasar (SD), Sekolah Menengah Pertama (SMP), Sekolah Menengah Atas (SMA), hingga Perguruan Tinggi (PT). Hal ini dilihat karena rerata hasil observasi data awal baik dari penelitian skripsi, tesis, hingga disertasi menunjukkan kesamaan masalah yakni para guru atau dosen masih berbasis "no name learning" atau “anonymous learning” (Corebima, 2016). Isitilah ini merujuk pada kegiatan berceramah, melakukan tanya jawab, memberi tugas serta menerapkan aneka teknik lain tanpa terkait dengan sesuatu model atau strategi pembelajaran. Namun, berbagai solusi yang telah dilakukan tidak cukup untuk mengatasi permasalahan ini dengan baik. Pernyataan ini didukung oleh hasil lembaga survei dari Programme for International Student Assessment (PISA) untuk aspek reading, science, dan mathematic. 
Hasil PISA untuk aspek reading literacy dari 2003, 2006, 2009, 2012, hingga 2015 menunjukkan bahwa posisi Indonesia selalu berada di bawah. Tahun 2003 posisi Indonesia berada di urutan 39 dari 40 negara (2 terendah), tahun 2006 posisi Indonesia berada pada urutan 49 dari 57 negara (9 terendah), tahun 2009 posisi Indonesia berada di posisi 57 dari 65 negara ( 9 terendah), tahun
2012 Indonesia menempati posisi 63 dari 67 negara (6 terendah), dan tahun 2015 Indonesia menempati posisi 61 dari 70 negara (9 terendah). Kemudian dilihat dari dari sebaran skor rerata reading literacy menunjukkan bahwa terjadi penurunan rerata dari hasil PISA 2009 ke PISA 2012 namun merangkak naik kembali di hasil PISA 2015. Hal ini dapat dilihat pada Tabel 1 .

Tabel 1. Reading Literacy Siswa Indonesia Tahun 2003, 2006, 2009, 2012, dan 2015 dalam Perbandingan dengan Beberapa Negara/Wilayah Lain

\begin{tabular}{|c|c|c|c|c|c|}
\hline $\begin{array}{c}\text { Negara/Wilayah } \\
\text { yang Disurvei }\end{array}$ & $\begin{array}{c}\text { PISA 2003 } \\
\text { (Skor Rerata) }\end{array}$ & $\begin{array}{c}\text { PISA 2006 } \\
\text { (Skor Rerata) }\end{array}$ & $\begin{array}{c}\text { PISA 2009 } \\
\text { (Skor Rerata) }\end{array}$ & $\begin{array}{c}\text { PISA 2012 } \\
\text { (Skor Rerata) }\end{array}$ & $\begin{array}{c}\text { PISA 2015 } \\
\text { (Skor Rerata) }\end{array}$ \\
\hline Korea & 534 & 556 & 539 & 536 & 517 \\
\hline Hongkong & 510 & 536 & 533 & 545 & 527 \\
\hline Japan & 498 & 498 & 520 & 538 & 516 \\
\hline Macau, China & 498 & 492 & 487 & 509 & 509 \\
\hline USA & 495 & - & 500 & 498 & 497 \\
\hline Thailand & 420 & 417 & 421 & 441 & 409 \\
\hline Indonesia & 382 & 393 & 402 & 396 & 397 \\
\hline
\end{tabular}

(Corebima, 2016; PISA, 2015)

Berbeda dengan aspek reading literacy, hasil PISA untuk aspek science literacy menunjukkan hasil yang cukup baik walaupun secara ranking Indonesia tetap dalam katagori 10 negara terendah. Pada tahun 2003 posisi Indonesia 38 dari 40 (3 terendah), pada tahun 2006 posisi Indonesia 50 dari 57 (8 terendah), pada tahun 2009 posisi
Indonesia 60 dari 65 (6 terendah), pada tahun 2012 posisi Indonesia 66 dari 67 (2 terendah), dan pada tahun 2015 Indonesia menempati posisi 61 dari 70 negara (9 terendah). Namun secara keseluruhan rerata science literacy Indonesia dari 2003-2015 mengalami peningkatan, hal ini dapat dilihat pada Tabel

Tabel 2. Science Literacy Siswa Indonesia Tahun 2003, 2006, 2009, 2012, dan 2015 dalam Perbandingan dengan Beberapa Negara/Wilayah Lain

\begin{tabular}{|c|c|c|c|c|c|}
\hline $\begin{array}{c}\text { Negara/Wilayah } \\
\text { yang Disurvei }\end{array}$ & $\begin{array}{c}\text { PISA 2003 } \\
\text { (Skor Rerata) }\end{array}$ & $\begin{array}{c}\text { PISA 2006 } \\
\text { (Skor Rerata) }\end{array}$ & $\begin{array}{c}\text { PISA 2009 } \\
\text { (Skor Rerata) }\end{array}$ & $\begin{array}{c}\text { PISA 2012 } \\
\text { (Skor Rerata) }\end{array}$ & $\begin{array}{c}\text { PISA 2015 } \\
\text { (Skor Rerata) }\end{array}$ \\
\hline Japan & 548 & 531 & 539 & 547 & 538 \\
\hline Hongkong & 539 & 542 & 549 & 555 & 523 \\
\hline Korea & 539 & 522 & 538 & 538 & 516 \\
\hline Macau, China & 525 & 511 & 511 & 521 & 529 \\
\hline USA & 491 & 489 & 502 & 497 & 496 \\
\hline Thailand & 429 & 421 & 425 & 444 & 421 \\
\hline Indonesia & 395 & 393 & 383 & 382 & 403 \\
\hline
\end{tabular}

(Corebima, 2016; PISA 2015)

Hasil PISA untuk aspek mathematic literacy juga menunjukkan posisi ranking yang cukup memprihatinkan. Pada tahun 2003 
posisi Indonesia 38 dari 40 ( 3 terendah), pada tahun 2006 posisi Indonesia 50 dari 57 (8 terendah), pada tahun 2009 posisi Indonesia 61 dari 65 (5 terendah), pada tahun 2012 tersebut posisi Indonesia 66 dari 67 (2 terendah), dan pada tahun 2015 Indonesia menempati posisi 61 dari 70 negara (9 terendah). Namun dilihat dari skor rerata mathematic literacy menunjukkan peningkatan rerata dari hasil PISA 2012 ke PISA 2015. Hal ini dapat dilihat pada Tabel 3.

Tabel 3. Mathematic Literacy Siswa Indonesia Tahun 2003, 2006, 2009, 2012, dan 2015 dalam Perbandingan dengan Beberapa Negara/Wilayah Lain

\begin{tabular}{|c|c|c|c|c|c|}
\hline $\begin{array}{c}\text { Negara/Wilayah } \\
\text { yang Disurvei }\end{array}$ & $\begin{array}{c}\text { PISA 2003 } \\
\text { (Skor Rerata) }\end{array}$ & $\begin{array}{c}\text { PISA 2006 } \\
\text { (Skor Rerata) }\end{array}$ & $\begin{array}{c}\text { PISA 2009 } \\
\text { (Skor Rerata) }\end{array}$ & $\begin{array}{c}\text { PISA 2012 } \\
\text { (Skor Rerata) }\end{array}$ & $\begin{array}{c}\text { PISA 2015 } \\
\text { (Skor Rerata) }\end{array}$ \\
\hline Korea & 542 & 547 & 546 & 554 & 524 \\
\hline Hongkong & 550 & 547 & 555 & 561 & 548 \\
\hline Japan & 534 & 523 & 529 & 536 & 532 \\
\hline Macau, China & 527 & 525 & 525 & 538 & 544 \\
\hline USA & 483 & 474 & 487 & 481 & 470 \\
\hline Thailand & 417 & 417 & 419 & 427 & 415 \\
\hline Indonesia & 360 & 391 & 371 & 375 & 386 \\
\hline
\end{tabular}

(Corebima, 2016; PISA, 2015)

Berdasarkan Tabel 1, 2, dan 3, diperoleh kesamaan persepsi bahwa secara ranking PISA baik dari 20032015, Indonesia selalu berada di 10 negara dengan urutan terendah. Padahal secara kuantitas penelitian di tingkat perguruan tinggi tergolong cukup besar. Semestinya kuantitas penelitian yang tinggi berimplikasi terhadap kualitas mutu pendidikan di Indonesia. Bahkan, ironisnya jika dilihat dari laporan data statistik pendidikan tinggi tahun 2017 , maka perguruan tinggi di Indonesia sudah meluluskan 1.046.141 mahasiswa (lihat Tabel 4.), artinya sudah ada 1.046.141 ide penelitian tercipta untuk tugas akhir (Menristekdikti, 2017).

Tabel 4. Data Lulusan dari Berbagai Perguruan Tinggi di Indonesia Hingga 2017

$\begin{array}{lrrrrr}\text { Lulusan / Graduates } & 355.017 & 33,94 & 691.124 & 66,06 & 1.046 .141 \\ \text { Universitas / University } & 314.675 & 47,26 & 351.221 & 52,74 & 665.896 \\ \text { Institut / Institute } & 14.340 & 34,57 & 27.140 & 65,43 & 41.480 \\ \text { Sekolah Tinggi / School of Higher Learning } & - & - & 226.026 & 100,00 & 226.026 \\ \text { Akademi / Academy } & - & - & 67.235 & 100,00 & 67.235 \\ \text { Akademi Komunitas/Community College } & 143.00 & - & 32 & - & 175 \\ \text { Politeknik / Polytechnic } & 25.859 & 57,05 & 19.470 & 42,95 & 45.329\end{array}$

Sumber: Menristekdikti, 2017.

Tabel 5. Data Dosen dari Berbagai Perguruan Tinggi di Indonesia Hingga 2017

Dosen / Lecturers

Universitas / University

Institut / Institute

Sekolah Tinggi / School of Higher Learning

Akademi / Academy

Akademi Komunitas/Community College

Politeknik / Polytechnic

Sumber: Menristekdikti, 2017.

$\begin{array}{rrrrr}73.607 & 29,77 & 173.662 & 70,23 & 247.269 \\ 61.042 & 39,60 & 93.115 & 60,40 & 154.157 \\ 4.992 & 45,66 & 5.942 & 54,34 & 10.934 \\ - & - & 52.122 & 100,00 & 52.122 \\ - & - & 16.688 & 100,00 & 16.688 \\ 5.00 & 18 & 23 & 82,14 & 28 \\ 7.568 & 56,73 & 5.772 & 4327 & 13.340\end{array}$


Berdasarkan jumlah dosen yang ber-NIDN ada sebanyak 247.269 (lihat Tabel 5), artinya ada 247.269 ide penelitian yang lahir dari akademisi perguruan tinggi melalui hibah dalam negeri dan luar negri (Menristekdikti, 2017). Bahkan jumlah dosen untuk bidang ilmu pendidikan berjumlah
39.458, artinya ada 39.458 ide penelitian bidang pendidikan yang dapat dilakukan baik melalui hibah dalam negeri dan luar negeri. Jumlah ini juga menempati peringkat 2 terbanyak setelah dosen bidang teknik (lihat Gambar

1).

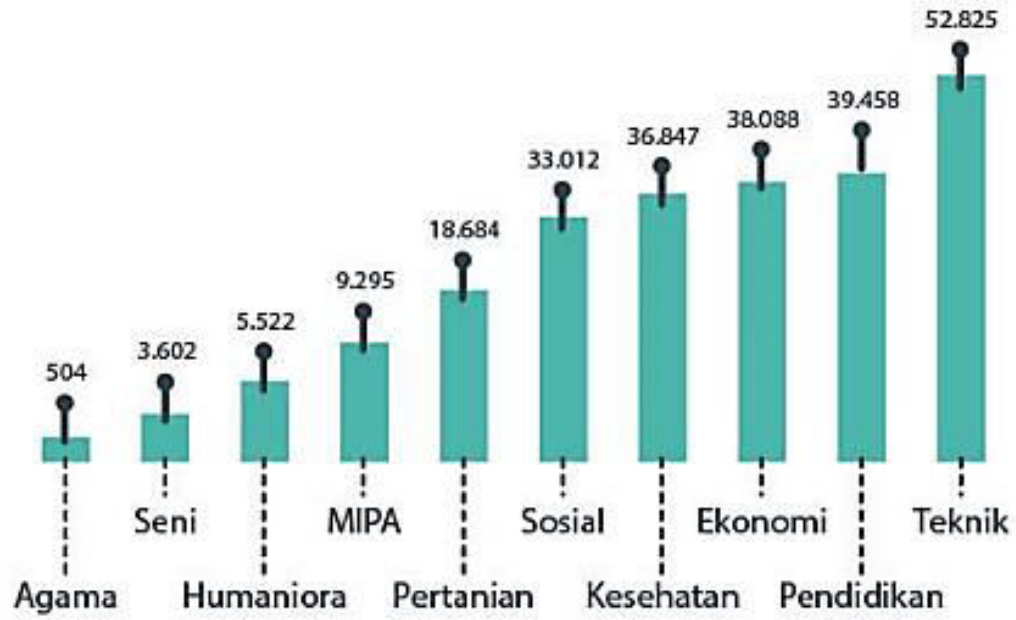

Gambar 1. Data Sebaran Dosen Kemenristekdikti Berdasarkan Bidang Ilmu Tahun Akademik 2016/2017 (Menristekdikti, 2016).

Selanjutnya, jika dilihat dari data jumlah program studi hingga 2017 untuk bidang ilmu pendidikan mencapai 3.394 program studi (Gambar 2) menempati peringkat 2 teratas setelah program studi bidang ilmu teknik.
Sehingga berdasar-kan data ini semestinya penelitian di bidang pendidikan dapat meingkatkan kualitas siswa Indonesia di ranking PISA namun realitanya tidak demikian.

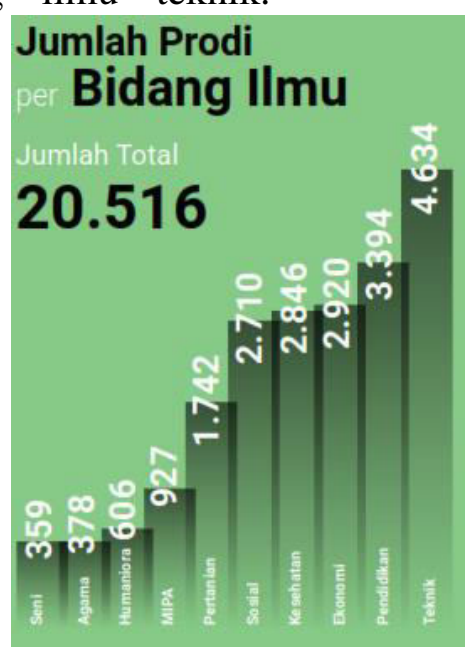

Gambar 2. Data Jumlah Program Studi Per Bidang Ilmu Hingga 2017 (Menristekdikti, 2017). 
Fakta ini cukup menarik karena gap yang terjadi antara potensi penelitian yang dapat dihasilkan dengan hasil survei PISA 2013-2015 sangatlah besar. Lantas apa yang sebenarnya terjadi dalam pelaksanaan penelitian di Indonesia? apa yang menjadi hambatan sehingga kualitas ranking Indonesia di PISA selalu berada di 10 negara terendah. Berikut uraiannya dalam kajian di bawah ini.

\section{PEMBAHASAN}

Hakikat sebuah penelitian merupakan suatu cara bagi seseorang untuk menyelesaikan suatu masalah. Pelaksanaan penelitian tidak terlepas dari prinsip dan kaidah proses ilimiah. Proses ilmiah merupakan suatu rangkaian pembuktian secara logika dan matematis untuk mencari solusi terhadap permasalahan yang didapat. Proses ilmiah sangat kental dengan paham konstruktivisme, yakni menempatkan pengetahuan dibangun atas dasar suatu konstruksi/langkah- langkah dalam pemecahan masalah. Proses ini sudah banyak digunakan oleh para ilmuwan dalam membuktikan suatu kebenaran pengetahun, baik dari zaman Yunani yang kita kenal dengan ilmuwan Aristoteles hingga ilmu pengetahuan modern sekarang ini.

Proses ilmiah membentuk 4 karakteristik yang menyatu dalam bidang ilmu sains (biologi), yakni rationality, truth, objectivity, dan realism (Gauch, 2003:41). Rationality/rasional merupakan suatu respon dan pembuktian terhadap keberhasilan penemuan dengan kebenaran logika. Truth/kebenaran merupakan nilai originilitas hasil dengan realita yang ada. Objectivity/objektif lebih kepada pembuktian objek secara fisik. Realism/realita merupakan aplikasi hubungan penemuan dalam kehidupan. Empat karakter inilah yang menjadi dasar bagi manusia dalam membangun pengetahuannya dengan langkahlangkah metode ilmiah.

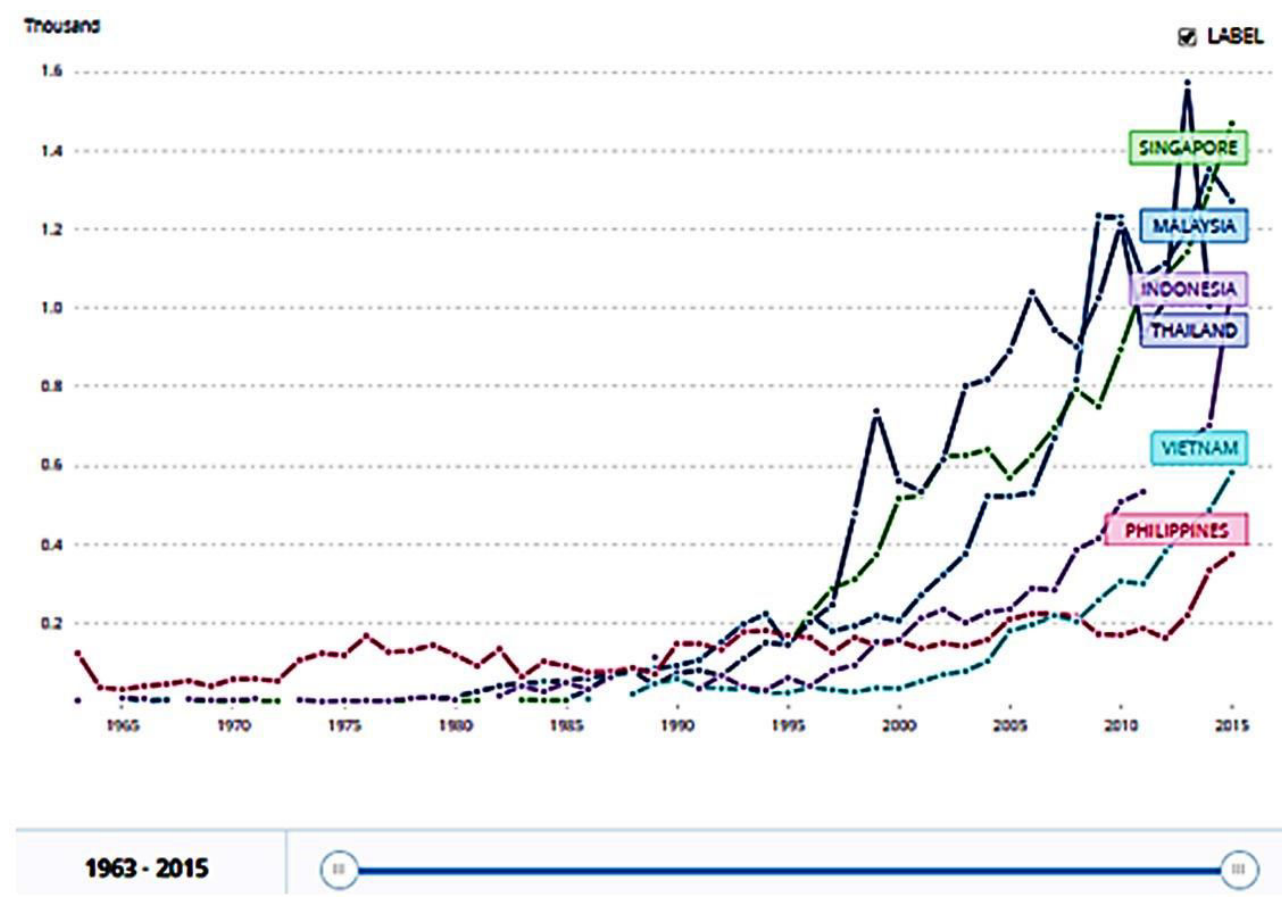

Gambar 3. Data Paten Tahun 1963-2015 untuk Beberapa Negara ASEAN (Bank, 2018). 
Ide penelitian menjadi ruh pelaksanaan penelitian yang berkualitas. Indikator kualitas penelitian yang baik akan tergambar dari jumlah sitasi artikel dan impact factor yang diberikan untuk kalangan luas. Selain itu, kualitas penelitian yang baik juga dapat dilihat dari jumlah paten yang dihasilkan. Berdasarkan data paten World Bank dari tahun 1963-2015 menunjukkan bahwa jumlah paten di Indonesia masih kalah banyak dengan Singapura dan Malaysia (lihat Gambar 3). Indonesia hanya memiliki 1.058 paten, Malaysia 1.272, dan Singapura 1.469. Namun Indonesia masih di atas Vietnam yang memiliki 582 paten, Thailand 1.006 paten, dan Filipina 375 paten. Walaupun demikian hasil PISA 2015, menunjukkan negera Vietnam masuk dalam 10 besar negara ranking atas, sedangkan Thailand meskipun berada di urutan negara nilai rendah namun masih di atas Indonesia. Berdasarkan uraian tersebut, lantas apa yang menyebabkan kualitas mutu penelitian belum memberikan dampak untuk mengatasi permasalahan pendidikan?

\section{Hambatan Penelitian di Level Kebijakan Pemerintah}

Munculnya rancangan

Permendagri Nomor 8 Tahun 2018 tentang Surat Keterangan Penelitian (SKP) memberikan polemik yang cukup banyak di kalangan akademisi. Kompas 7 Februari 2018 mengutip pernyataan Menteri Dalam Negeri Tjahjo Kumolo menyatakan bahwa tujuan diterbitkan SKP itu sebagai bentuk tertib administrasi dan pengendalian pelaksanaan penelitian dalam rangka kewaspadaan terhadap dampak negatif yang diperkirakan akan timbul dari proses penelitian (Nadlir, 2018). Namun kebijakan ini dirasakan akan menyulitkan kegiatan penelitian dan mengkerdilkan demokrasi para akademisi untuk berkarya dan memberikan masukan. Jika dilihat dari sisi kepentingan pemerintah dapat disimpulkan bahwa kebijakan ini merupakan salah satu wujud kebijakan politis menjelang pemilihan Presiden 2019 yang kemudian menjadi pembatas bagi akademisi untuk melakukan penelitian.

Selanjutnya, jika dilihat dari trend kebijakan pemotongan anggaran penelitian yang dilakukan oleh pemerintah, memberikan dampak pengurangan minat akademisi untuk mengajukan ide penelitian. Pernyataan pemotongan anggaran ini senada dengan pernyataan Hasanudin Abdurakhman, pada kolom opini di website Litbang Kemendagri, 9 Februari 2018 yang berbunyi:

"Anggaran indikatif Lembaga Ilmu Pengetahuan Indonesia (LIPI) turun dari Rp 1,1783 triliun untuk alokasi 2016 menjadi Rp 1,1662 triliun untuk tahun 2017. Anggaran yang sama untuk Badan Pengkajian dan Penerapan Teknologi (BPPT) turun dari Rp 977,1 miliar menjadi Rp 949,1 miliar. Kemudian juga diberitakan bahwa anggaran penelitian dan pengabdian masyarakat di perguruan tinggi juga dipotong dari Rp 250 miliar menjadi Rp 150 miliar (Abdurakhman, 2018)".

Seiring dengan penciptaan pertumbuhan atmosfer peneliti di Indonesia, kondisi ini tentunya menjadi keprihatinan bagi para akademisi di kalangan perguruan tinggi. Pemerintah justru menerapkan pemotongan anggaran dengan dalih untuk efesiensi anggaran dan efektivitas penerimaan ide penelitian dari pada memperbanyak penerimaan penelitian yang akan didanai. 
2. Kurangnya Peneliti Berkualifikasi S3

Tidak dapat dipungkiri bahwa peneliti berkualifkasi S3 di Indonesia masih dirasakan sangat kurang dan tidak sebanding dengan pertumbuhan peneliti S3 di beberapa negara seperti Taiwan, China, Korea Selatan, dan Singapura (Aswatini, 2014; Corebima, 2016). Hal ini dilihat pada Gambar 4.

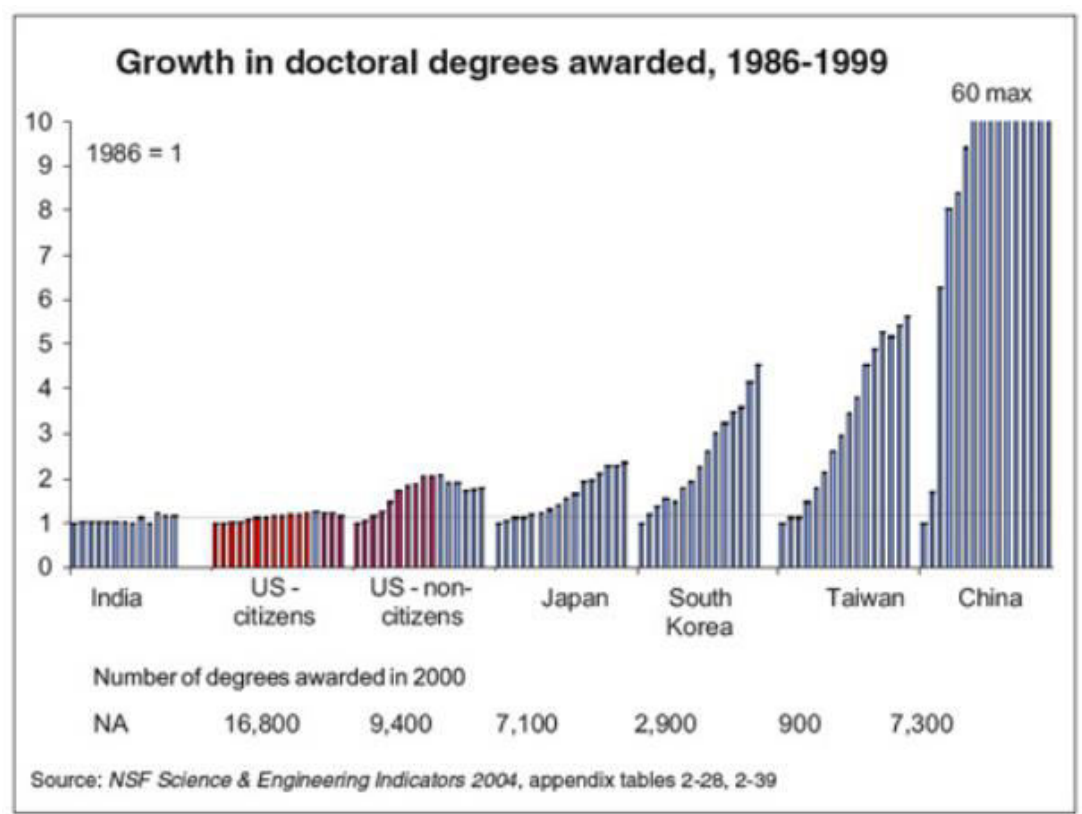

Gambar 4. Pertumbuhan Jumlah Doktor 1986-1999 (Hicks, 2004).

Fakta ini juga didukung oleh data dari Forlap Dikti 2018 yang menunjukkan jumlah dosen berkualifikasi S3 masih rendah ketimbang kualifikasi S2, hal ini dapat dilihat pada Gambar 5. Gambar 5 menjelaskan bahwa, jumlah dosen berkualifikasi S3 sebesar 36.938 dosen, kualifikasi S2 sebesar 187.452 dosen, dan kualifikasi S1 sebesar 36.848 dosen. Namun secara trend jumlah dosen S3 2014/20152016/2017 mengalami peningkatkan.

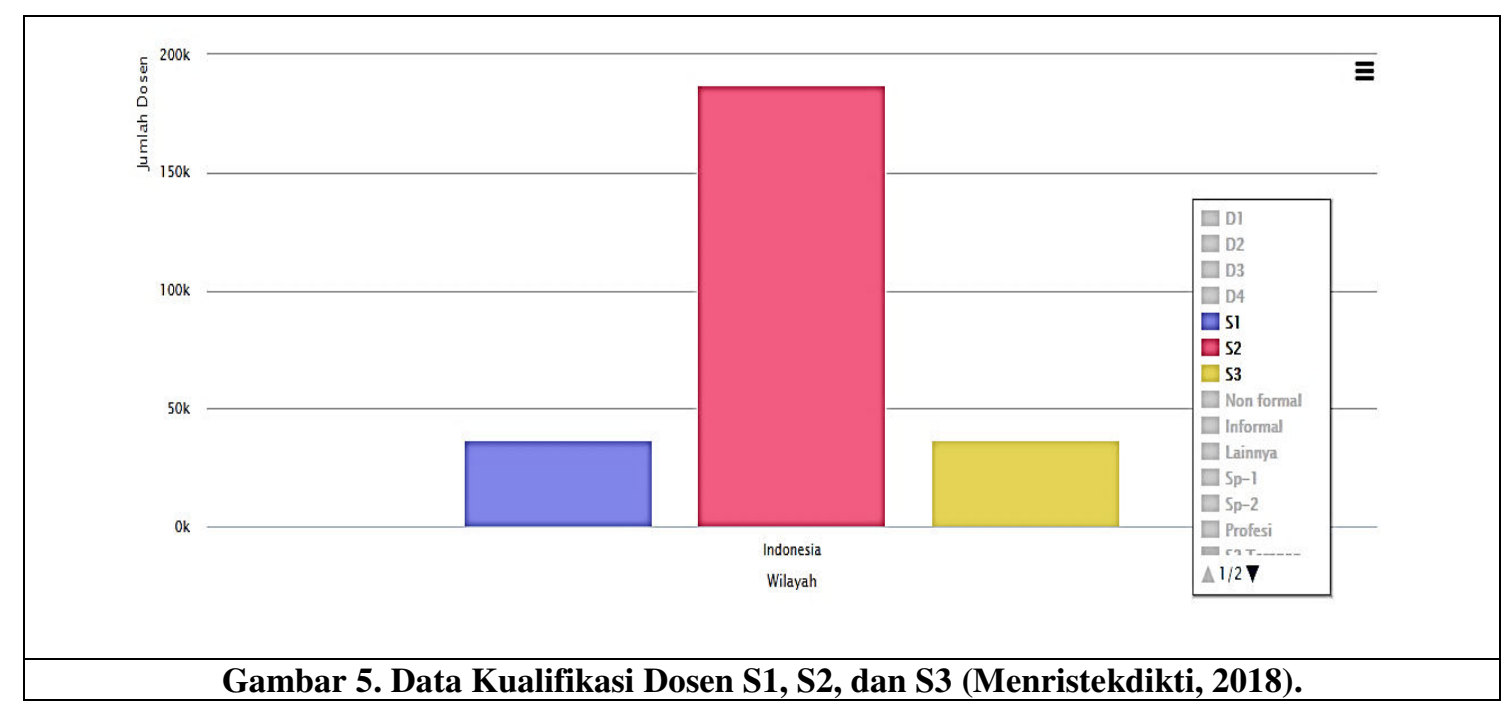


Hal ini memberikan gambaran keberhasilan usaha pemerintah untuk menggiatkan para dosen untuk melanjutkan kuliah S3 dengan program beasiswa (BU, BPPDN, BPPLN,
BUDIDN, BUDILN, dan LPDP) sudah tampak dan meningkatkan jumlah dosen kulifkasi S3. Hal ini dapat dilihat pada Gambar

6.

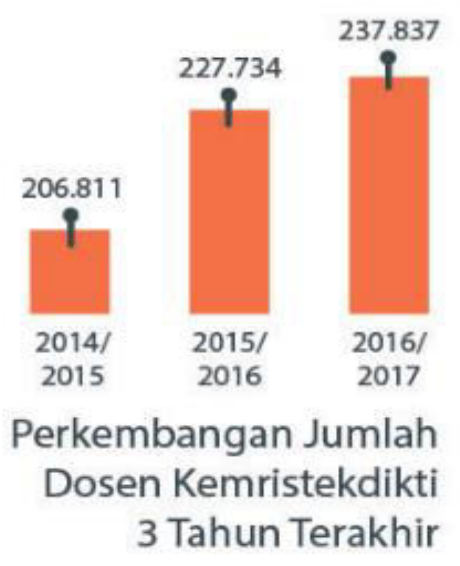

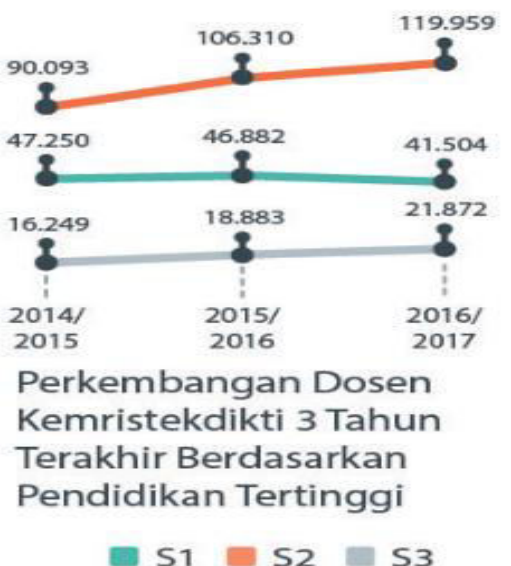

- $51=52=53$

Gambar 6. Perkembangan Jumlah Dosen Kemristekdikti 3 Tahun Terakhir (Menristekdikti, 2016).

\section{Potensi Pertumbuhan Atmosfer Peneliti di Indonesia}

Pertumbuhan atmosfer peneliti membutuhkan dana dan minat yang tidak sedikit. Jika dilihat dari data total pertumbuhan peneliti 2005-2015 dari Organisation for Economic Co- operation and Development (OECD) menunjukkan bahwa pertumbuhan atmosfer peneliti di beberapa negara Asia sangatlah tinggi dan bahkan di atas baseline OECD (warna hitam) hal ini dapat dilihat pada Gambar 7.

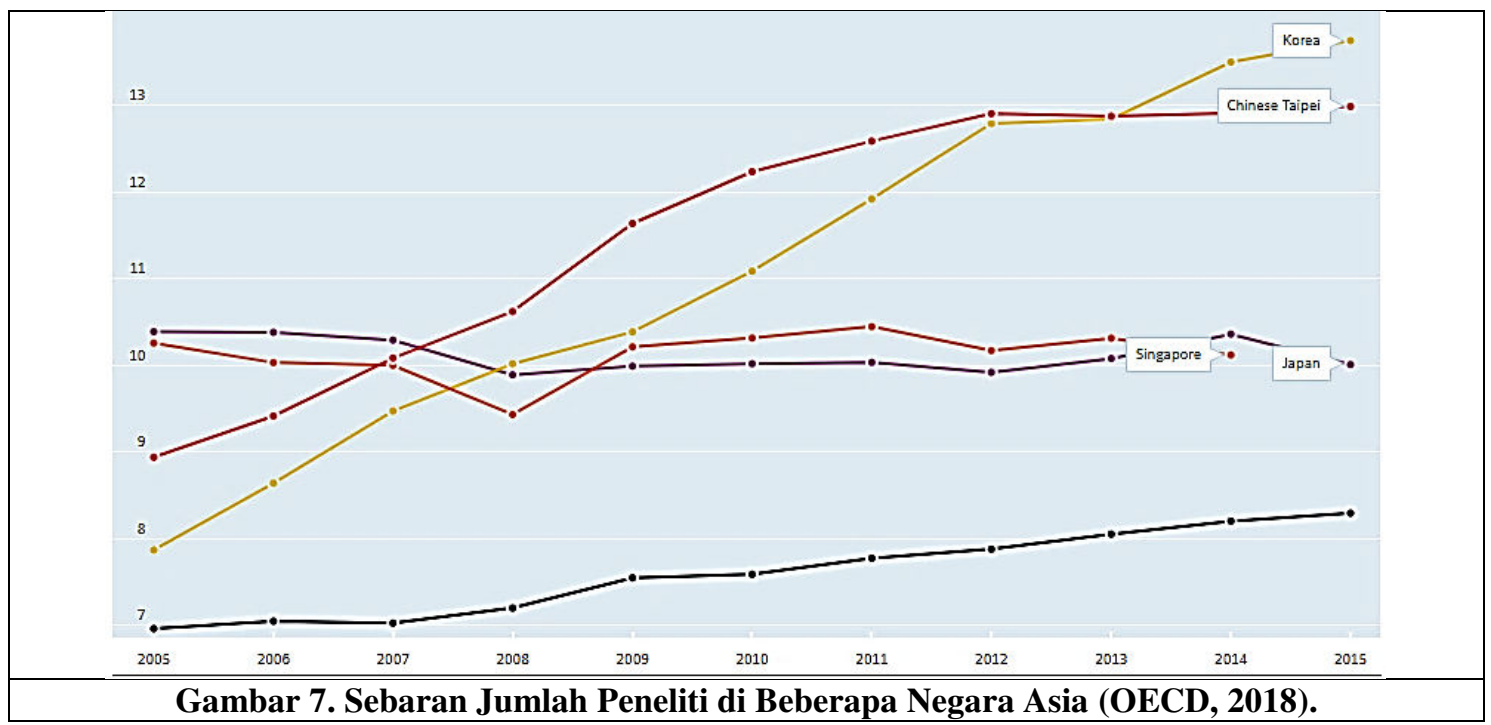


Selanjutnya, fakta ini tidak sejalan dengan kondisi di Indonesia, pernyataan ini didukung data dari World Bank Group 2014 yang menggambarkan bahwa pertumbuhan atmosfer penelitian di Indonesia antara 2009-2012 masih sangat rendah (lihat Tabel 6) (Corebima, 2016).

Tabel 6. Jumlah Peneliti Terkait $R \& D$ di Beberapa Negara, Per 1 Juta Penduduk (Antara Tahun 2009-2012)

\begin{tabular}{|l|r|r|r|r|}
\hline \multirow{2}{*}{ Negara/Wilayah } & \multicolumn{5}{|c|}{$\begin{array}{c}\text { Jumlah Peneliti R \& D } \\
\text { Per 1 Juta Penduduk }\end{array}$} \\
\cline { 2 - 5 } & $\mathbf{2 0 0 9}$ & $\mathbf{2 0 1 0}$ & $\mathbf{2 0 1 1}$ & $\mathbf{2 0 1 2}$ \\
\hline China & 853 & 890 & 963 & 1.020 \\
\hline Hongkong & 2.752 & 2.925 & - & - \\
\hline Macao & 487 & 503 & 476 & - \\
\hline Jepang & 5.147 & 5.151 & 5.158 & - \\
\hline Korea & 5.068 & 5.451 & 5.928 & - \\
\hline Singapura & 6.150 & 6.307 & 6.494 & 6.438 \\
\hline USA & 4.042 & 3.938 & 3.979 & - \\
\hline Thailand & 332 & - & - & - \\
\hline Malaysia & 1.065 & 1.459 & 1643 & \\
\hline Indonesia & 90 & - & - & - \\
\hline
\end{tabular}

(World Bank Grup, 2014 dalam Corebima, 2016).

Berdasarkan uraian yang telah disampaikan, berikut upaya yang dapat dilakukan untuk meningkatkan mutu penelitian dalam mengatasi permasalahan pendidikan.

\section{Upaya yang Dilakukan untuk Meningkatkan Mutu Penelitian \\ Berdasarkan kajian tentang} penyebab terjadinya penurunan mutu penelitan di Indonesia, maka beberapa upaya yang dilakukan sebagai berikut:

\section{Penciptaan Kebijakan yang}

\section{Kondusif untuk Para Akademisi}

Kebijakan menjadi acuan dasar untuk melakukan sebuah penelitian. Penciptaan kebijakan yang kondusif akan memudahkan para akademisi untuk melakukan penelitian. Kebijakan yang baik dan tepat akan memberikan dampak yang efektif dalam membangun pertumbuhan atmosfer peneliti di Indonesia. Kerjasama Kemenristekdikti dengan lembaga funding dari luar negeri memberikan kekuatan finansial yang baru. Kekuatan ini akan mengem-bangkan potensi para peneliti di Indonesia dan bersaing secara global.

2. Penambahan Kuota Penerimaan Beasiswa Dosen S3 untuk Usia di bawah Usia 40 Tahun

Penambahan kuota penerimaan beasiswa dosen S3 usia di bawah usia 40 tahun akan meningkatkan minat para dosen untuk melanjutkan kualifikasi S3. Dosen usia di bawah 40 tahun memiliki kemampuan konsentrasi yang cukup baik dan kreativitas yang sangat tinggi. Harapannya akan muncul beberapa ide penelitian yang lebih inovatif dalam mengatasi permasalahan pendidikan. Selain itu, kerjasama Kemenristekdikti dengan beberapa Universitas dari luar negeri ternama untuk membuka program studi di Indonesia, memberikan efesiensi pendanaan beasiswa bagi Kemenristekdikti dan mendorong dosen untuk melanjutkan S3. 


\section{Penambahan Kuota Anggaran untuk Penelitian}

Penambahan kuota anggaran untuk penelitian juga akan meningkatkan minat akademisi dalam melakukan penelitian. Peningkatan minat ini diharapkan dapat menjadi pendorong pertumbuhan atmosfer peneliti di Indonesia dan berdampak pada jumlah paten yang dapat memberikan dampak dalam mengatasi permasalahan pendidikan.

4. Integrasi Hasil Penelitian kepada Para Guru dalam Meningkatkan Proses Pembelajaran

Integrasi hasil penelitian dapat diterapkan melalui kegiatan Pengabdian kepada Masyarakat (PkM). Kegiatan PkM memberikan sosialisasi dan pelatihan bagi para guru untuk mengenalkan hasil-hasil penelitian pendidikan dan menerapkan hasil penelitian ke dalam pembelajaran di dalam kelas. Hal ini dikarenakan hasil penelitian mengenai model, media, metode, dan modul telah banyak terbukti dalam meningkatkan kemampuan siswa baik secara kognitif, maupun secara afektif, dan psikomotorik (Ali, 2009; Anwar, Sudjimat, \& Suhartadi, 2012; Handhika, 2012; Haryoko, 2009; Kurniawan, 2013; Mariati, 2012; Mediawati, 2011; Putri, 2013; Rahmatullah, 2011; Rahmawati, Sudargo, \& Paramastri, 2007; Winarno, 2009).

\section{KESIMPULAN}

Secara kuantitas penelitian Indonesia sudah tergolong banyak, namun memerlukan sistem pengelolaan yang baik dengan pemetaan hilirisasi penelitian kepada masyarakat yang jelas. Ada 3 faktor utama yang meyebabkan kualitas penelitian di Indonesia masih rendah 1) hambatan di level kebijakan pemerintah; 2) kurangnya peneliti kuali-fikasi S3, dan 3) rendahnya potensi pertumbuhan atmosfer penelitian di Indonesia. Upaya yang dapat dilakukan 1) penciptaan kebijakan yang kondusif untuk para peneliti; 2) penambahan kuota penerimaan beasiswa dosen S3 untuk usia di bawah 40;3) penambahan kuota anggaran untuk penelitian, dan 4) Integrasi hasil penelitian kepada para guru dalam meningkatkan proses pembelajaran.

\section{UCAPAN TERIMA KASIH}

Penulis mengucapkan terima kasih kepada pihak yang telah memberikan dukungan untuk dalam penulisan artikel ini.

\section{DAFTAR PUSTAKA}

Abdurakhman, H. (2018, Februari 8). Anggaran dan Berbagai Masalah. Retrieved from http://www.litbang.kemendagri.go.i d/

Ali, M. (2009). Pengembangan Media Pembelajaran Interaktif Mata Kuliah Medan Elektromagnetik. Jurnal Edukasi Elektro, 5(1).

Anwar, K., Sudjimat, D. A., \& Suhartadi, S. (2012). Pengaruh Media Pembelajaran Dua Dimensi, Tiga Dimensi, dan Bakat Mekanik terhadap Hasil Belajar Sistem Pengapian Motor Bensin di SMK Kota Mojokerto. Teknologi dan Kejuruan, 32(2).

Aswatini. (2014, September 18). Empat Masalah Penelitian Indonesia Versi LIPI. Diambil kembali dari http://www.lipi.go.id/

Bank, W. (2018, Februari 8). Patent Applications, Residents. Diambil kembali dari https://data.worldbank.org/indicator /IP.PAT.RESD?end=2015\&locatio $n s=M Y-S G-T H-P H-$ 
ID\&name_desc $=$ false \&start $=1963$ \&view=chart.

Corebima, A. (2016). Pembelajaran Biologi di Indonesia Bukan untuk Hidup. Proceeding Biology Education Conference (hal. 8-22). Surakarta: Universitas Negeri Surakarta.

Gauch, H. (2003). Scientific Method in Practice. London: University Press, Cambridge.

Hick, D. (2004). Real Number: Asian Countries Strengthen Their Research. Issues in Science and Technology, 20.

Menristekdikti. (2016). Laporan Tahunan. Jakarta: Kementerian Riset, Teknologi, dan Pendidikan Tinggi.

Menristekdikti. (2017). Statistik Pendidikan Tinggi. Jakarta: Kementerian Riset, Teknologi, dan Pendididikan Tinggi.

Menristekdikti. (2018, Februari 11). Jumlah Dosen Berdasarkan Kualifikasi. Diambil kembali dari https://forlap.ristekdikti.go.id/dosen /homegraphjenjang.

Nadlir, M. (2018, Februari 9). Menuai Kritik, Permendagri Soal Pengaturan Penelitian Akhirnya Dibatalkan. Diambil kembali dari http://.www.kompas.com/

OECD. (2016). PISA 2015 Result in Focus. Paris: OECD.
OECD. (2018). OECD Data Researchers. Paris: OECD.

Putri, C. (2013). Pengaruh Kreativitas Belajar, Penggunaan Media Pembelajaran Power Point, dan Lingkungan Keluarga Terhadap Hasil Belajar Mata Pelajaran Akuntansi pada Siswa Kelas X AKT SMK Negeri 2 Blora Tahun Ajaran 2012/2013 (Motivasi Belajar Sebagai Variabel Interval). Economic Education Analysis Journal, 2(2).

Rahmatullah, M. (2011). Pengaruh Pemanfaatan Media Pembelajaran Film Animasi terhadap Hasil Belajar. Jurnal Penelitian Pendidikan, 12(1), 178-186.

Rahmawati, I., Sudargo, T., \& Paramastri, I. (2007). Pengaruh Penyuluhan dengan Media Audio Visual terhadap Peningkatan Pengetahuan, Sikap dan Perilaku Ibu Balita Gizi Kurang dan Buruk di Kabupaten Kotawaringin Barat Provinsi Kalimantan Tengah. Jurnal Gizi Klinik Indonesia, 4(2), 69-77.

Winarno, A. (2009). Pengembangan Model Pembelajaran Internalisasi NilaiNilai Kewirausahaan pada Sekolah Menengah Kejuruan di Kota Malang. Jurnal Ekonomi Bisnis, 14(2), 124-131. 